\title{
Harpiosquilla raphidea, Udang Belalang Komoditas Unggulan dari Provinsi Jambi
}

\author{
[Harpiosquilla raphidea, the mantis shrimp as the leading commodities from \\ Jambi]
}

\author{
Sukarni' ${ }^{1}$, Rina $^{2}$, Ade Samsudin ${ }^{1}$, Yefni Purna $^{1}$ \\ 1'Stasiun Karantina Ikan, Pengendalian Mutu dan Keamanan Hasil Perikanan Jambi \\ ${ }^{2}$ Badan Karantina Ikan, Pengendalian Mutu dan Keamanan Hasil Perikanan
}

Diterima: 25 September 2018; Disetujui: 29 November 2018

\begin{abstract}
Abstrak
Harpiosquilla raphidea merupakan jenis udang belalang asli Jambi yang bersifat predator. Pemberian nama udang belalang didasarkan pada bentuk morfologinya yang menyerupai udang dan bentuk capit depannya seperti belalang sembah. Udang belalang memiliki 6-8 segmen abdomen dan mempunyai telson berwarna kuning yang ditandai dengan dua bintik cokelat gelap yang dikelilingi warna putih. Metoda yang digunakan dalam penelitian ini adalah desk study terhadap data primer, wawancara dan penelusuran berbagai penelitian terkait. Hasil analisa pada data pengiriman Harpiosquilla raphidea dari Jambi menunjukan trend peningkatan dari tahun 2015-2017 dengan rata-rata 23.38\% pertahun, yaitu: tahun 2017 sebanyak 3.785 .059 ekor, 2016 sebanyak 3.164.420 ekor dan 2015 sebanyak 2.488 .867 ekor. Sampai saat ini untuk memperoleh Harpiosquilla raphidea masih mengandalkan tangkapan dari alam, oleh karena itu tulisan ini bertujuan untuk mengkaji data pengirimannya dari Jambi beberapa tahun terakhir yang akan berpengaruh terhadap kelestariannya di alam. Sejauh ini belum ada penelitian dan budidaya secara lengkap, mulai dari domestikasi calon induk, pemijahan, penetasan telur, pemeliharaan larva dan pembesaran. Upaya yang dilakukan sampai sekarang baru sebatas pemeliharaan di tempat penampungan sebelum dilakukan pengiriman keluar Jambi.
\end{abstract}

Kata kunci: Harpiosquilla raphidea; udang belalang asli Jambi; predator

\section{Abstract}

Harpiosquilla raphidea is a type of native Jambi grasshopper that is predatory. The name of grasshopper shrimp is based on the morphological shape that resembles a shrimp and its front claw shape is like a praying mantis. Grasshopper shrimp has 6-8 abdominal segments and has a yellow telson marked by two dark brown spots surrounded by white. The method used in this study is desk study of primary data, interviews and various research related searches. The results of the analysis on the shipping data of Harpiosquilla raphidea from Jambi showed an increasing trend from 2015-2017 with an average of $23.38 \%$ per year, namely: in 2017 as many as 3,785,059 tails, in 2016 as many as $3,164,420$ tails and 2015 as many as $2,488,867$ tails. Until now to get Harpiosquilla raphidea still relies on catching from nature, therefore this paper aims to examine the shipping data from Jambi in the last few years which will affect its sustainability in nature. So far there is no complete research and cultivation, ranging from prospective parent domestication, spawning, egg hatching, larval rearing and enlargement. The efforts that have been carried out until now are limited to maintenance at the shelter before sending out Jambi.

Keywords: Harpiosquilla raphidea; locust shrimps native to Jambi; predators

Penulis korespondensi

Ade Samsudin | ski.jbi@gmail.com 


\section{PENDAHULUAN}

Indonesia merupakan negara kepulauan terluas didunia,wilayahnya terdiri dari daratan dan lautan dengan jumlah pulau sekitar 17.508 pulau. Luas daratan Indonesia adalah $1.919 .440 \mathrm{~km}^{2}$ yang menempatkan Indonesia sebagai negara ke 15 terluas di dunia. Wilayah Indonesia terbentang sepanjang 3.977 mil dari Samudera Indonesia hingga Samudera Pasifik. Ini menjadikan Indonesia memiliki lautan yang luas sekitar $\quad 3.273 .810 \mathrm{~km}^{2}$. Lautan Indonesiapun memiliki batas sesuai hukum laut internasional, yaitu dengan menggunakan teritorial laut sepanjang 12 mil laut serta zona ekonomi eksklusif sepanjang 200 mil laut. Luasnya lautan Indonesia ini membawa keberkahan bagi bangsa Indonesia. Sumber daya alam yang terkandung di dalam lautan sangat banyak dan bermanfaat untuk mensejahterakan rakyat Indonesia.

Sebagai negara kepulauan, perairan Indonesia kaya akan berbagai sumberdaya hayati yang dapat dimanfaatkan untuk kesejahteraan masyarakat, terdiri dari pisces (ikan bersirip), crustaceae (udang, kepiting, rajungan dan sebangsanya), molusca (kerang, tiram, cumi-cumi, gurita, siput dan sebagainya), coelenterata (uburubur dan sebangsanya), echinodermata (tripang, bulu babi dan sebangsanya), amphibia (kodok dan sebangsanya), reptilian (buaya, penyu, kura-kura, biawak, ular air dan sebangsanya), mamalia (paus, lumba-lumba, pesut, duyung dan sebangsanya), dan algae (rumput laut dan tumbuh-tumbuhan lain yang hidupnya di dalam air).

Udang belalang merupakan salahsatu jenis crustaceae laut yang sangat digemari untuk dikonsumsi dengan kandungan protein mencapai $87,09 \%$.Udang belalang disukai, terutama di luar negeri seperti Singapura, Malaysia, Cina, Jepang, Thailand, Filipina, Hongkong, bahkan sangat populer di negara-negara Mediterania sampai ke Eropa. Udang belalang tidak banyak dikonsumsi di dalam negeri karena harganya termasuk tinggi. Harga di tingkat sulplier adalah adalah sebagai berikut: size kecil $(\mathrm{K})$ Rp7.000, cukup (C) Rp17.000, sedang (B) Rp20.000, besar (A) Rp25.000, special (SP) Rp70.000 dan jumbo (JB) Rp75.000 per ekor.

\section{Klasifikasi, Deskripsi, Jenis dan Morfologi}

Menurut Astuti dan Ariestyani (2013) udang belalang merupakan spesies udang laut, termasuk dalam filum Arthropoda, subfilum Crustacea, dan ordo Stomatoda. Terdapat 5 superfamili yaitu Bathysquilloidea, Gonodactyloidea, Erythrosquilloidea dan Squilloidea, dan terdiri atas 20 famili (Astuti dan Ariestyani, 2013), dimana 
genus Harpiosquillla dari famili Squillidae termasuk stomatoda terbesar, dan Harpiosquilllaraphidea (Fabricius) adalah spesies terbesar yang bisa mencapai panjang total lebih dari $300 \mathrm{~mm}$ (Astuti dan Ariestyani, 2013, Manning, 1969).

Udang belalang (Harpiosquilla raphidea) merupakan jenis udang yang bersifatpredator.Pemberiannama udang belalang didasarkan pada bentuk morfologinya yang menyerupai udang dan bentuk capit depannya seperti belalang sembah (praying mantis). Klasifikasi udang belalang menurut Lovett (1981) adalah sebagai berikut:

Kingdom: Animalia

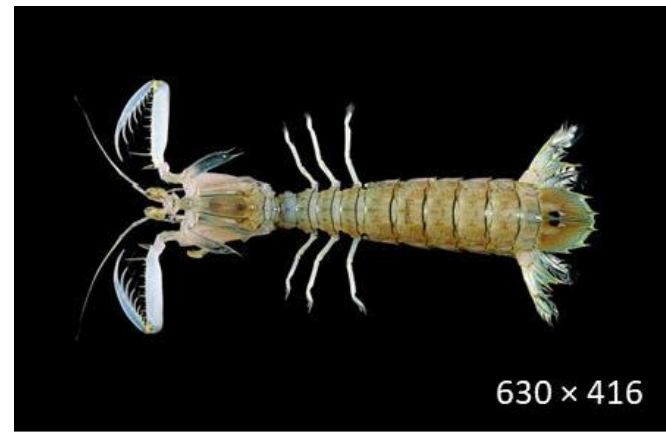

Gambar 1. Harpoisquilla harpax taibif.tw/zh/namecode/403223

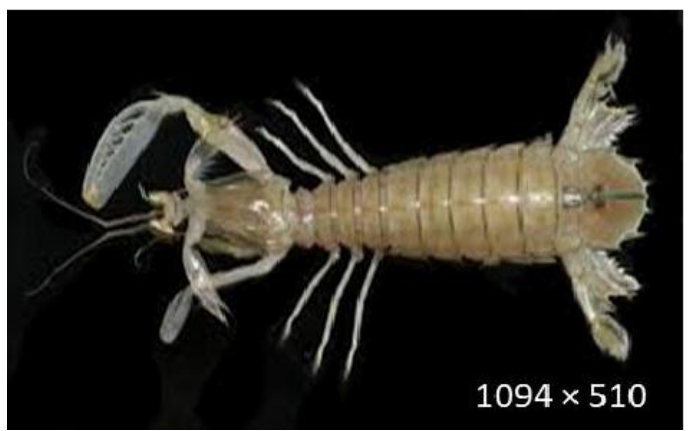

Gambar 3. Harpiosquilla raphidea http://ranong.myspecies.info
Filum: Arthropoda

Subfilum: Crustacea

Kelas: Malacostraca

Subkelas: Hoplocarida

Ordo: Stomatopoda

Famili: Squillidae

Genus: Harpiosquilla

Spesies: Harpiosquilla raphidea

Udang belalang disebut juga udang lipan, udang getak, udang mentadak, udang eiko, udang ronggeng, dan udang mantis, dalam Bahasa Inggris disebut mantis shrimp atau juga praying shrimp. Di daerah Serang, Banten udang ini disebut udang cakrek atau udang pletok,

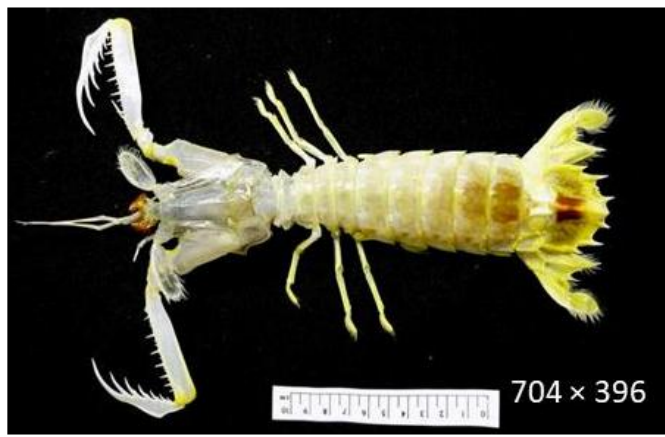

Gambar 2. Harpiosquilla stephensoni http://museum.wa.gov.au/explore

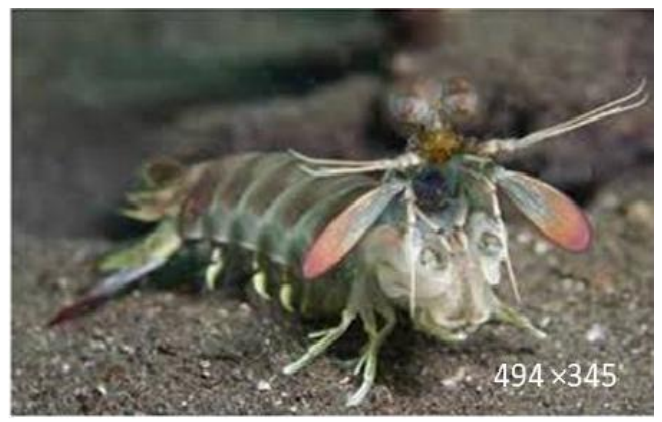

Gambar 4. Haptosquilla glyptocercus ejournal.balitbang.kkp.go.id 


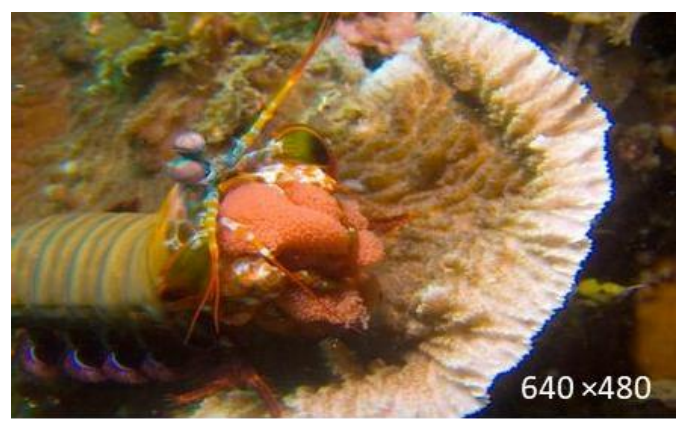

Gambar 5. Haptosquilla hamifera https://www.nano.reef.com

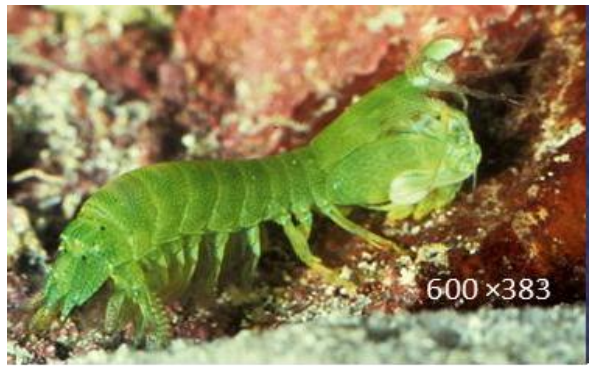

Gambar 7. Gonodactylus viridis https://reefcentral.com

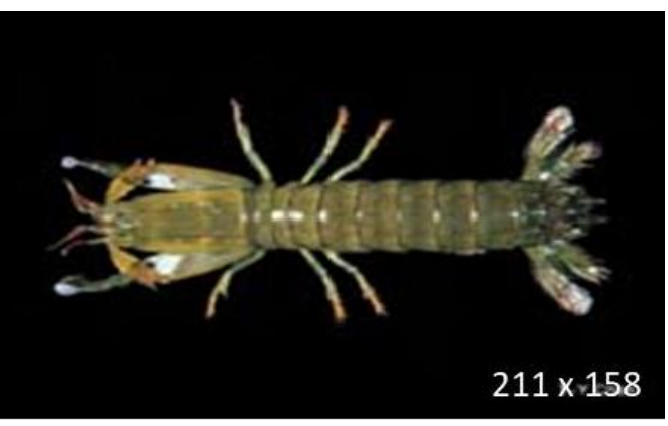

Gambar 6. Gonododactylus annularis https://www.nano.reef.com

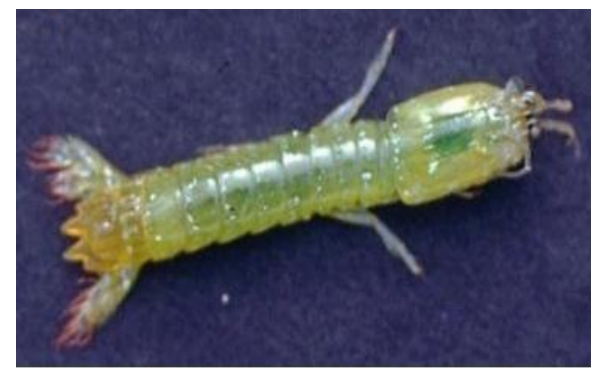

Gambar 8. Gonodactylus erdmanni https://decapoda.free.fr

Di perairan seluruh dunia terdapat sekitar 400 jenis (spesies) udang belalang, terutama di perairan tropis dan subtropis. Beberapa jenis udang belalang dapat dilihat pada Gambar 1-13.

Udang belalang memiliki bentuk badan unik, yang merupakan kombinasi morfologi dari udang, lobster dan belalang sembah. Ukuran udang belalang bisa mencapai $35 \mathrm{~cm}$ dengan bobot antara 20- 200 gram per ekor. Jenis udang belalang beraneka warna mulai dari warna gelap, cokelat, hingga berwarna terang. Beberapa spesies udang belalang memiliki fluorescence atau zat yang membuat badannya terlihat bercahaya dalam kegelapan. 


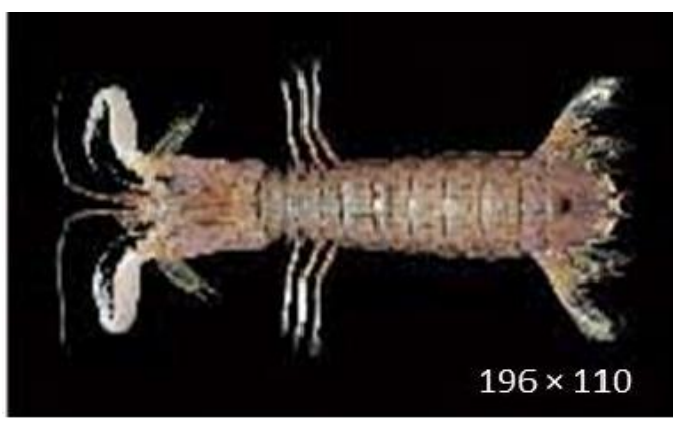

Gambar 9. Gonodactylus rubiguttatus ejournal.balitbang.kkp.go.id

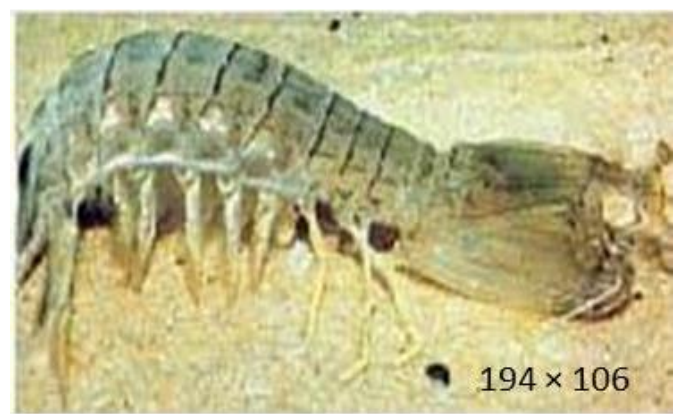

Gambar 11. Chrisquilla hystrix ejournal.balitbang.kkp.go.id

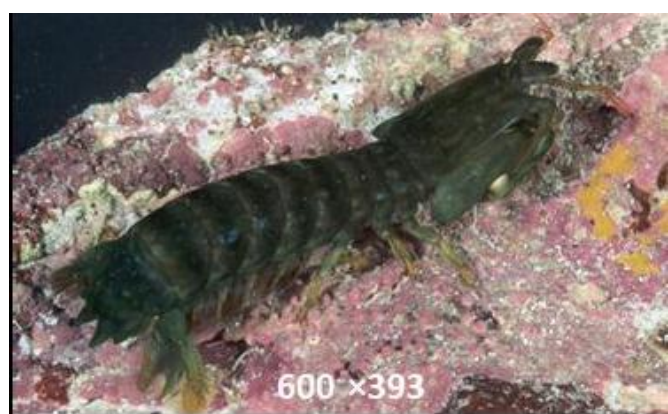

Gambar 10. Gonodactylus chiragra https://www.ucmp.berkeley.edu

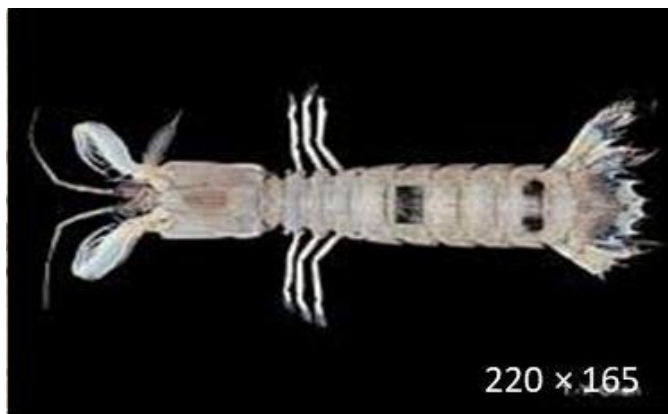

Gambar 12. Carinosquilla multicarinata https://www.biosearch.in

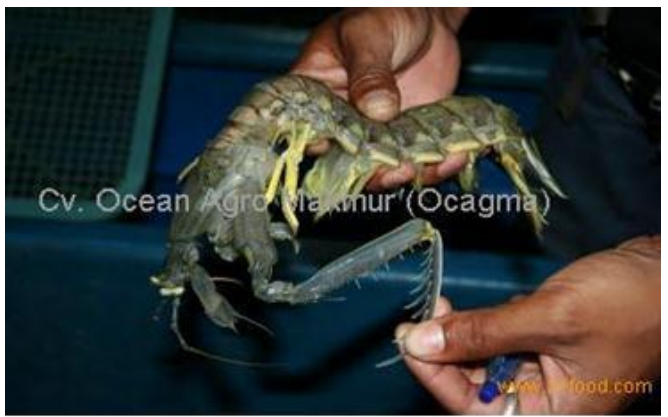

Gambar 13. Oratosquillina gravieri

https://www.21food.com

Udang belalang termasuk hewan karnivora dan termasuk hewan aktif di siang hari (diurnal), malam hari (nocturnal) maupun saat matahari terbenam (crepuscular). Udang belalang termasuk salah satu jenis udang predator yang mampu menyerang mangsa dengan ukuran lima kali lebih besar dari ukuran badannya (Astuti dan Ariestyani, 2013).

Secara morfologi, udang belalang memiliki garis hitam pada bagian belakang antara antenna dan ophthalmic somite, antenula yang menghasilkan zat warna hitam berpusat pada bagian tepi anterior, celah antara torasic somite, 


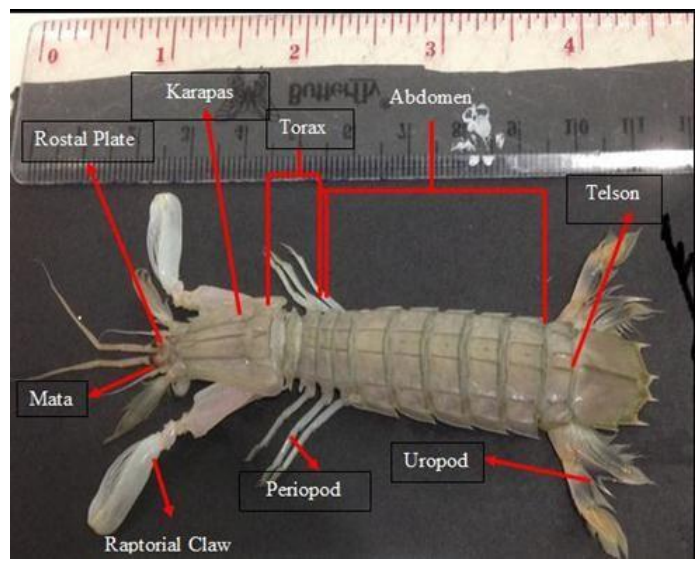

Gambar 14. Bagian tubuh udang belalang (Situmeang dkk 2017)

serta garis tepi antara anterior dan posteriomada karapas. Karapas hanya menutupi sebagian kepala dan tiga segmen pertama dari toraks. Permukaan badan udang belalang berwarna kekuningan, sepasang antenna dengan abdomen terdiri dari 10 ruas dan telson memiliki enam buah duri kecil. Uropoda bagian dalam dan luar berwarna hitam dan mempunyai bulu-bulu halus, mempunyai serta celah torasic dengan tiga bagian propundus yang mempunyai duri-duri kecil yang tajam, dan telson dipisahkan oleh garis yang berwarna hitam (Anonim, 2012). Mulai dari kepala, kedua sisi badannya, sampai ekor memiliki senjata sangat tajam sehingga perlu hati-hati ketika menangkap jenis udang ini.

Keunikan dari udang belalang adalah mempunyai dua mata yang dapat berputar 360 derajat yang berfungsi sebagai radar. Udang ini mempunyai mata super yang dapat melihat warna pantulan cahaya ultraviolet hingga infra merah, dapat membedakan kombinasi 11-12 warna primer, dan memiliki kemampuan melihat langsung warna cahaya yang berbeda-beda dari polarisasi cahaya (Astuti dan Ariestyani, 2013).

Bagian tubuh udang belalang terdiri dari antenula, antenna, mata, karapas, rostral plate, raptorial claw, torax, abdomen, periopod, pleopod, uropod dan telson sebagaimana dapat dilihat pada Gambar 14.

\section{Habitat}

Udang belalang dapat hidup di air laut maupun air payau, dan sering dijumpai di daerah pesisir maupun pertambakan. Habitat sebagian besar udang belalang adalah pantai, senang hidup di dasar air terutama pasir berlumpur. Di Kalimantan Barat, pada umumnya udang belalang toleran terhadap salinitas antara 14-24 ppt. Jenis 
udang belalang yang hidup di laut dengan kadar salinitas lebih tinggi biasanya hanya mencapai ukuran 6-12 cm saja (Anonim, 2011). Asstalavista (2012) dalam Astuti dan Ariestyani (2013) menyatakan bahwa spesies Harpiosquilla raphidea hidup di daerah intertidal dengan hamparan berlumpur (mudflat) dengan kedalaman lumpur antara 50-200 cm; salinitas berkisar 12 19 ppt; oksigen terlarut pada kisaran 6,77,6 mg/L; pH pada kisaran 7,1-7,8; dan suhu pada kisaran $28,5^{\circ} \mathrm{C}-30,5^{\circ} \mathrm{C}$.

Jenis udang belalang yang lain dilaporkan hidup di antara terumbu karang yang sangat kompleks (Green, 2008 dalam Astuti dan Ariestyani, 2013), dan memiliki peran penting dalam ekosistem terumbu karang sebagai bioindikator dalam ekosistem laut, yaitu dengan menjaga populasi dan memelihara semua spesies yang ada baik secara langsung maupun tidak langsung. Perilaku hidup dari udang belalang yang menggali lubang pada terumbu karang memberi peluang untuk oksigenasi sehingga kesehatan terumbu karang akan lebih terjaga (Barber dkk 2000 dalam Pujawan dkk, 2012). Udang belalang terkenal sebagai spesies monogamy yang sangat setia dengan pasangannya hingga 20 tahun dalam masa hidupnya. Dalam seumur hidup, udang belalang mengalami 20 sampai 30 kali pemijahan. Jantan dan betina bersama- sama hanya pada saat memijah. Setelah terjadi pembuahan, telur diletakkan dan disimpan dalam liang, atau disimpan di bawah ekor betina sampai menetas, tergantung spesiesnya. Setelah telur menetas, larva dapat membutuhkan waktu selama tiga bulan sebagai plankton. Choi dalam Dewinta (2010) menyatakan bahwa udang betina mampu bertelur sebanyak 50.000 hingga 1 juta telur, yang akan menetas setelah 24 jam dan menjadi larva nauplius.

Tahap perkembangan larva pada udang belalang terdiri atas empat fase. Fase pertama adalah nauplius, larva nauplius tidak dapat berenang sehingga terbawa arus kemana saja arus bergerak, terutama arus yang sejajar garis pantai, bermetamorfosis dalam enam stages berkisar selama dua hari. Fase kedua yaitu protozoea, mempunyai tujuh pasang anggota badan, bermetamorfosis dalam tiga stages berkisar selama tujuh hari. Fase ketiga yaitu mysis bermetamorfosis dalam tiga stages berkisar selama tujuh hari. Fase keempat (terakhir) yaitu postlarva,pada fase ini udang mulai memiliki karakteristik udangdewasa, dilanjutkan menjadi yuwana dan udang dewasa.

\section{Daerah Penyebaran}

Di Indonesia, data mengenai spesies, jumlah, dan daerah penyebarannya belum pernah 
dilaporkan. Namun demikian, terdapat beberapa data mengenai spesies dan asal spesies yang pernah ditemukan, diantaranya Harpiosquilla harpax banyak ditemukan di Pantai Utara Jawa, Selat Malaka sampai ke Laut Pasifik (Ahyong dkk, 2008). Di perairan Pemuteran, Bali terdapat empat spesies udang belalang yaitu Haptosquilla glyptocercus, Gonodactylus annularis, Gonodactylus viridis, dan Chrisquilla hystrix (Pujawan, 2012). Spesies Haptosquillahamiferadan Gonodactyllelus erdmanni terdapat di perairan Sulawesi (Plaisance dkk dalam Pujawan, 2012), spesies Gonodactyllelus rubiguttatus terdapat di perairan Komodo dan spesies Gonodactylus chiragra terdapat di Laut Jawa (Porter dkk, 2010). Sedangkan di perairan Cirebon terdapat spesies Harpiosquilla harpax (Dewinta, 2010), Harpiosquilla stephensoni dan Carinosquilla multicarinata, dan di perairan Aceh terdapat spesies Carinosquilla multicarinata (Syafrina dan Raisa, 2011). Mashar (2011) meneliti udang belalang asal Kuala Tungkal, Jambi dari spesies Harpiosquilla raphidea dan Oratosquillina gravieri. Di perairan yang sama juga ditemukan spesies Harpiosquilla harpax dan Harpiosquilla raphidea, dengan lebih didominasi oleh spesies Harpiosquilla raphidea (Wardianto, 2009). Di Laut Jawa dan Laut Cina Selatan merupakan daerah penyebaran udang belalang dari famili Harpiosquillidae dan Squillidae (Syafrina dan Raisa, 2011).

\section{Budidaya Udang Belalang}

Udang belalang diperoleh dari hasil tangkapan nelayan di perairan umum laut, yang ketersediaannya sangat tergantung pada musim. Hingga saat ini udang belalang belum di budidayakan secara menyeluruh dan komersial, berbeda dengan budidaya udang windu dan udang budidaya lainnya yang sudah memasyarakat dan termasuk target dalam industrialisasi perikanan.

Usaha pemeliharaan udang belalang sudah dilakukan dan benihnya bukan dari hasil pemijahan tetapi hasil tangkapan dari alam yang ditampung di dalam bak pemeliharaan, baik di keramba jaring apung (KJA) maupun di tambak. Pemeliharaan biasanya dilakukan untuk jangka waktu yang berbeda-beda dengan maksud untuk membesarkan udang belalang yang tidak/belum memenuhi ukuran pasar. Pakan yang diberikan adalah ikan rucah yang dipotong besar. Biasanya udang belalang dipelihara dalam keadaan hidup di dalam botol plastik yang di tampung dalam bak atau akuarium sebelum diperdagangkan atau dimasak. Udang belalang akan mendekap pakan yang diberikan dengan kedua capit besarnya, 
dan memakan pakan yang diberikan sedikit demi sedikit.

Upaya budidaya secara lengkap dan menyeluruh sudah waktunya untuk mulai dilakukan dalam rangka antisipasi terjadinyapenurunanvolume perdagangan udang belalang yang berasal dari hasil tangkapan alam yang semakin lama tentu saja akan semakin berkurang akibat penangkapan tidak terkendali dan tidak memperhatikan kelestariannya. Menurut Astuti dan Ariestyani (2013) domestikasi udang belalang sebagai langkah awal dalam usaha budidaya perlu dilakukan segera sebelum semuanya terlambat. Oleh karena itu perlu dilakukan penelitian/kajian tentang berbagai aspek udang belalang seperti aspek biologi, ekologi, reproduksi, genetika,dan lainlain.

\section{Kandungan Gizi Udang Belalang.}

Menurut Jacoeb, dkk (2008) udang belalang segar memiliki nilai rendemen $41,13 \%$ daging; $54,25 \%$ cangkang; dan $4,62 \%$ jeroan. Komposisi kimia terdiri dari kadar air berat basah (bb) 76,55 \%; abu berat kering (bk) 5,41\%; protein (bk) $87,09 \%$, dan lemak (bk) 6,57 \%. Kadar vitamin, yaitu vitamin A 81,77 $\mu \mathrm{g} / 100 \mathrm{~g}$; vitamin B6 0,15 $\mu \mathrm{g} / 100 \mathrm{~g}$; dan vitamin B12 1,29 $\mu \mathrm{g} / 100 \mathrm{~g}$. Udang ronggeng rebus memiliki nilai rendemen, yaitu $20,08 \%$ daging; 45,32 \% cangkang; dan
$1,69 \%$ jeroan dengan nilai rendemen yang hilang sebesar 32,9 \%. Komposisi kimia, yaitu kadar air (bb) 73,1\%; abu (bk) 5,37\%; protein (bk) 86,36 \%; lemak (bk) 3,20\%. Kadar vitamin, yaitu vitamin A $62,42 \mu \mathrm{g} / 100 \mathrm{~g}$; vitamin B6 0,11 $\mathrm{mg} / 100 \mathrm{~g}$; dan vitamin B12 0,77 $\mu \mathrm{g} / 100$ g. Perebusan dapat menurunkan nilai rendemen cangkang, jeroan, daging kadar air, lemak, protein, abu serta kandungan vitamin $\mathrm{A}, \mathrm{B} 6$, dan B12 udang ronggeng.

\section{BAHAN DAN METODE}

Bahan yang diperlukan untuk kegiatan ini terdiri dari buku/jurnal/karya tulis dan laporan lalu-lintas hasil perikanan yang melalui Stasiun Karantina Ikan, Pengendalian Mutu dan Keamanan Hasil Perikanan Jambi. Metode yang digunakan dalam kegiatan ini adalah desk study terhadap data primer, wawancara dan penelusuran berbagai penelitian terkait.

\section{HASIL DAN PEMBAHASAN \\ Pengiriman Udang Belalang dari Jambi}

Sebagian besar udang belalang yang biasa dikirim ke Jakarta dari Jambi merupakan jenis Harphiosquilla raphidea. Pengiriman dilakukan melalui cargo bandara Sultan Thaha Jambi.Udang belalang yang dikirim dari Jambi ke Jakarta selanjutnya diekspor ke berbagai negara. Sampai saat ini udang 
Tabel 1. Volume komoditas ikan domestik keluar melalui SKIPM Jambi 2015-2017

\begin{tabular}{|c|c|c|c|c|c|c|c|}
\hline \multirow{3}{*}{ No } & \multirow{3}{*}{ Jenis komoditas } & \multicolumn{6}{|c|}{ Volume } \\
\hline & & \multicolumn{2}{|c|}{2015} & \multicolumn{2}{|c|}{2016} & \multicolumn{2}{|c|}{2017} \\
\hline & & Ekor & $\mathrm{Kg}$ & Ekor & $\mathrm{Kg}$ & Ekor & $\mathrm{Kg}$ \\
\hline 1 & Bahan Olahan Asal Ikan & - & 204 & - & 366 & - & 99 \\
\hline 2 & Bawal & - & 39,145 & - & 84,841 & - & $73,697.50$ \\
\hline 3 & Belida & - & 202 & - & 82 & - & 83.2 \\
\hline 4 & Betutu & 23,001 & - & 17,877 & - & 9,456 & - \\
\hline 5 & Botia & 64,370 & - & 156,190 & - & 556,165 & - \\
\hline 6 & Coklat Gurame & 99,850 & - & 94,870 & - & 116,470 & - \\
\hline 7 & Udang Hias & 145,105 & - & 106,650 & - & 105,250 & - \\
\hline 8 & Cupang & 26,500 & - & 15,483 & - & 61,354 & - \\
\hline 9 & Frozen Tilapia fillet & - & 4,910 & - & - & - & 5 \\
\hline 10 & Gelembung Renang Ikan & - & 796 & - & 861 & - & 923.4 \\
\hline 11 & Goby & 46,250 & - & 41,350 & - & 51,350 & - \\
\hline 12 & Ikan Cunang / Malong & - & 1,200 & - & 6,018 & - & $10,630.00$ \\
\hline 13 & Ikan Segar / Beku & - & 3,280 & - & 1,751 & - & $11,651.50$ \\
\hline 14 & Kepiting & 10,793 & - & 65 & - & 8,592 & - \\
\hline 15 & Lele & 800 & - & 20,000 & - & 17 & - \\
\hline 16 & Patin Segar & - & 175 & - & 95 & - & 119 \\
\hline 17 & Seluang & 447,356 & - & 532,904 & - & 431,930 & - \\
\hline 18 & Susur Batang & 106,255 & - & 75,200 & - & 141,609 & - \\
\hline 19 & Tali-tali & 602,900 & - & 561,700 & - & 566,400 & - \\
\hline 20 & Tenggiri Segar & - & 115 & - & 37 & - & $1,639.00$ \\
\hline 21 & Tilan & 56,390 & - & 85,945 & - & 41,615 & - \\
\hline 22 & Udang Belalang & $2,488,867$ & - & $3,164,420$ & - & $3,785,059$ & \\
\hline 23 & Udang Laut & - & 13,507 & - & 3,044 & - & - \\
\hline 24 & Ikan Lainnya & 352,384 & 2,813 & 290,405 & 4,254 & - & - \\
\hline & TOTAL & $4,470,821$ & 66,346 & $5,163,059$ & 101,349 & $5,875,267$ & $98,847,6$ \\
\hline
\end{tabular}

Sumber: BKIPM Jambi dalam angka 2018

belalang belum bisa diekspor langsung dari Jambi karena dari bandara Sultan Thaha Jambi belum ada penerbangan internasional. Informasi yang kami dapat dari PT. Angkasa Pura II Cabang Jambi pada tahun 2019 direncanakan akanada penerbangan internasional. Pada tahun ini sedang dibangun fasilitas perpanjangan run-away dan gedung terminal untuk penumpang internasional. Udang belalang dikemas dalam plastik bekas minuman air mineral ataupun lainnya sebanyak 1 ekor per botol plastik. Kemudian disusun rapi 
dalam kantong plastik besar, diisi oksigen, diikat rapat dan selanjutnya dimasukan ke dalam dus serta diisolasi.Setiap dus berisi 50 ekor udang belalang.

Udang belalang termasuk produk unggulan hasil perikanan dari Provinsi Jambi.Keberhasilan dalam perdagangan udang belalang ini berdampak positif terhadap peningkatan kesejahteraan masyarakat khususnya nelayan-nelayan disekitar Kabupaten Tanjung Jabung Barat danTanjung Jabung Timur, Propinsi Jambi. Pengiriman udang belalang (domestik keluar) yang disertifikasi di Stasiun Karantina Ikan Pengendalian Mutu dan Keamanan Hasil Perikanan (SKIPM) Jambi dan dikirim melalui bandara Sultan Thaha pada tahun 2015 sebanyak 2.488.867 ekor dengan nilai Rp. 49.777.340.000. Pada tahun 2016 meningkat $27.14 \%$ menjadi 3.164.420 ekor dengan nilai Rp. 63.288.400.000. Sedangkan pada tahun 2017 meningkat $19.61 \%$ dari tahun sebelumnya menjadi 3.785.059 ekor dengan nilai Rp. 264.954.130.000. Ratarata peningkatan volume pengiriman udang belalang dari Jambi dalam kurun waktu tiga tahun dari tahun 2015-2017 adalah sebesar $23.38 \%$ Data pengiriman udang belalang selama tiga tahun dari tahun 2015-2017 disajikan pada Tabel 1.
Nilai komoditi udang belalangtahun 2016 sebesar Rp. 63.288.400.000 dibanding tahun 2015 sebesar Rp. 48.777.340.000, terjadi peningkatan sebesar Rp. 13.511.060.000, sedangkan pada tahun 2017 sebesar Rp. 264.954.130.000 dibanding tahun 2016 sebesar Rp. 63.288.400.000, terjadi peningkatan yang sangat tinggi yaitu sebesar Rp. 201.665.730.000. Perbedaan yang sangat tinggi disebabkan oleh perbedaan harga. Pada Tabel 1.

Pada tahun 2015 dan 2016 suplier mengirimkan udang belalang ke Jakarta dalam berbagai ukuran yang sangat bervariatif sehingga harganya hanya $\mathrm{Rp}$. 20.000 per ekor, sedangkan pada tahun 2017 hanya dikirim udang belalang untuk keperluan ekspor dengan harga rata-rata mencapai Rp. 70.000 per ekor. Udang belalang berukuran kecil yang tidak bisa dijual ke luar negeri (ekspor) oleh pemilik ditampung sementara atau dijual di pasar tradisional untuk memenuhi keperluan masyarakat lokal. Nilai udang belalang yang dikirim melalui bandara Sultan Thaha Jambi ke Jakarta disajikan pada Tabel 2.

Udang belalang yang diperdagangkan saat ini masih berupa hasil tangkapan dari alam (perairan laut), bukan hasil budidaya secara menyeluruh. Selama tiga tahun terakhir 2015-2017 udang belalang yang 
Tabel 2. Nilai komoditas ikan domestik keluar melalui SKIPM Jambi tahun 2015-2017

\begin{tabular}{|c|c|c|c|c|}
\hline & \multirow{2}{*}{ No } & \multicolumn{3}{|c|}{ Nilai (Rp) } \\
\hline & & 2015 & 2016 & 2017 \\
\hline 1 & Bahan Olahan Asal Ikan & $4,080,000$ & $7,320,000$ & $9,900,000$ \\
\hline 2 & Bawal & $782,900,000$ & $1,696,810,000$ & $8,843,700,000$ \\
\hline 3 & Belida & $4,040,000$ & $1,640,000$ & $4,160,000$ \\
\hline 4 & Betutu & $460,020,000$ & $357,540,000$ & $378,240,000$ \\
\hline 5 & Botia & $1,287,400,000$ & $3,123,800,000$ & $556,165,000$ \\
\hline 6 & Coklat Gurame & $1,997,000,000$ & $1,897,400,000$ & $151,411,000$ \\
\hline 7 & Udang Hias & $2,902,100,000$ & $2,133,000,000$ & $84,200,000$ \\
\hline 8 & Cupang & $530,000,000$ & $309,660,000$ & $72,395,200$ \\
\hline 9 & Frozen Tilapia fillet & $98,200,000$ & 0 & 200,000 \\
\hline 10 & Gelembung Renang Ikan & $15,924,000$ & $17,216,000$ & $5,540,000$ \\
\hline 11 & Goby & $925,000,000$ & $827,000,000$ & $61,620,000$ \\
\hline 12 & Ikan Cunang / Malong & $24,000,000$ & $120,360,000$ & $265,750,000$ \\
\hline 13 & Ikan Segar / Beku & $65,600,000$ & $35,020,000$ & $2,499,675,000$ \\
\hline 14 & Kepiting & $215,860,000$ & $1,300,000$ & $257,760,000$ \\
\hline 15 & Lele & $16,000,000$ & $400,000,000$ & 75,000 \\
\hline 16 & Patin Segar & $3,490,000$ & $1,900,000$ & $2,380,000$ \\
\hline 17 & Seluang & $8,947,120,000$ & $10,658,080,000$ & $597,045,000$ \\
\hline 18 & Susur Batang & $2,125,100,000$ & $1,504,000,000$ & $141,609,000$ \\
\hline 19 & Tali-tali & $12,058,000,000$ & $11,234,000,000$ & $849,600,000$ \\
\hline 20 & Tenggiri Segar & $2,300,000$ & 740,000 & $98,340,000$ \\
\hline 21 & Tilan & $1,127,800,000$ & $1,718,900,000$ & $332,920,000$ \\
\hline 22 & Udang Belalang & $49,777,340,000$ & $63,288,400,000$ & $264,954,130,000$ \\
\hline 23 & Udang Laut & $270,130,000$ & $60,880,000$ & 0 \\
\hline 24 & Ikan Lainnya & $5,471,632,800$ & $3,529,092,000$ & 0 \\
\hline & TOTAL & $89,111,036,800$ & $102,924,058,000$ & $280,166,815,200$ \\
\hline
\end{tabular}

Sumber: BKIPM Jambi dalam angka 2018

diperdagangkan jumlahnya semakin meningkat. Penangkapan di alam sepertinya tidak terkendali dan kebiasaan nelayan melakukan penangkapan berbagai ukuran yang tidak selektif mulai dari ukuran kecil,sedang, besar dan bertelor semakin menghawatirkan akan kelestarian sumberdaya udang belalang tersebut.

\section{SIMPULAN DAN SARAN}

Peningkatan volume perdagangan udang belalang berdampak positif terhadap peningkatan kesejahteraan masyarakat nelayan dengan nilai jual 
udang belalang yang relative tinggi.Selain itu sektor ini juga mampu menyerap tenaga kerja di lingkungan sekitar daerah penangkapan udang belalang, tentu hal ini berdampak pada pengurangan pengganguran.

Perdagangan udang belalang yang berorientasi pada ekpor ke manca negara juga berkontribusi pada penerimaan devisa negara, sehingga turut membantu pembangunan negara. Regulasi yang mengatur tentang penangkapan udang belalang belum ada, sehingga pemanfaatannya dari alam tidak terkontrol. Masyarakat mengakap udang belalang dari alam tanpa memperhatikan ukuran yang ditangkap dan tanpa batasan ukuran yang dilakukan secara terus menerus, tentu hal ini mengancam kelestariannya. Perlu dipertimbangkan untuk membuat regulasi yang mengatur penagkapan udang belalang di alam, yang meliputi tentang batasan ukuran yang boleh ditangkap dan tidak boleh ditangkap sertalarangan penangkapan dan perdagangan untuk udang belalang yang sedang bertelur. Perlu segera dilakukan penelitian untuk budidaya udang belalang dalam rangka mengurangi ketergantungan pada penangkapan di alam dan menjaga kontinyuitas ketersediaan pasokan untuk memenuhi permintaan konsumen. Selain itu juga perlu dilakukannya sebuah penelitian tentang trend dan kajian stock kelimpahan dialam dan populasi udang belalang sehingga dapat ditentukan Maximum Stock Yield (MSY) dalam rangka pemanfaatan udang belalang secara berkelanjutan dan lestari

\section{DAFTAR PUSTAKA}

Ahyong, S.T., Chan T.Y., \& Liao, Y.C. 2008. A catalogue of mantis shrimps (Stomatopoda) of Taiwan. National Taiwan Ocean University: Keelung.

Anonim.2011.Carinosquilla multicarinata (White,1848) (Mantis Shrimp).

http://www.biosearch.in/publicOrga nismPage.php?id=130155. 12 Juli 2018

Anonim. 2010. Lime Green Mantis ID. http://www.reefcentral.com/forums/ showthread.php?t=1864264. 12 Juli 2018

Anonim. 2012. Udang lipan (Mantis shrimp). http://zonaikankita.blogspot.com. 11 Juli 2018

Anonim. 2012. Udang kipas/udang lipan/ udang ronggeng / mantis shrimp. http://info-budidaya.blogspot.com. 11 Juli 2018

Astuti, I.R., dan Ariestyani, F. (2013) Potensi dan prospek ekonomis udang mantis di Indonesia. Media Akuakultur, 8 (1): 39-44. 
Broek, J. V. D. 2010. Peacock mantis shrimp.

https://www.flickr.com/photos/shar kjames/5490557864/. 17 Juli 2018

Coldwell, R. 2005. Roy's Listof Stomatopods for the Aquarium. http://www.ucmp.berkeley.edu/arth ropoda/crustacea/malacostraca/eu malacostraca/royslist/species.php ?na me=g_chiragra

Dewinta, Achmad, F., \& Yusli, W. 2010. Pola distribusi geografis pada udang mantis di Pantai Jawa berdasarkan genom mitokondria. Departemen Biologi. FMIPA, Institut Pertanian Bogor.

Gonser, J. 2003. Large shrimp thriving in Ala Wai Canal muck. Honolulu Advertiser.

Hosie, A. 2012. Creature Feature Stephenson's Mantis Shrimp. http://museum.wa.gov.au/explore/ blogs/andrew-hosie/creaturefeaturestephenson-s-mantisshrimp. 11 Juli 2018

Jacoeb, A. M., \& Hamdani, M. (2010). Perubahan Komposisi Kimia dan Vitamin Daging Udang Ronggeng (Harpiosquilla raphidea) Akibat Perebusan. Jurnal Pengolahan Hasil Perikanan Indonesia, 11(2).

Lovett, D. L. (1981)..A guide to the shrimps, prawns, lobters, and crabs of Mataysia and Singapore.
Faculty of Fisheries and Marine Science. Universiti Pertanian Malaysia.

Manning, R.B. 1969. A Review of the genus Harpiosquilla (Crustacea, Stomatoda), with descriptions of three new species. Smithsonian Contributions to Zoology 36. Smithsonian Institution Press. City of Washington.

Mashar, A. 2011. Distribusi spasial udang mantis Harpiosquilla raphidea dan Oratosquillina gravieri di Kuala Tungkal, Kabupaten Tanjung Jabung Barat Provinsi Jambi. http://repository.ipb.ac.id

Porter, M.L., Zhang, Y., Desai, S., Caldwell, R.L., \& Cronin, T.W. 2010. Evolution of anatomical and physiological specializations in the compound eyes of stomatopod crustaceans. J. Exp. Biol. 213 pp.

Pujawan, A.G.N.O., Tjok, S.N., \& I Gusti, N.K.M. 2012. Identifikasi spesies udang mantis (Stematoda) di perairan Pemuteran dengan menggunakan gen cytochrome $\mathrm{C}$ oxidase subunit1 dari DNA mitokondria. Indonesia Medicus Veterinus, 1(2): 268-280.

Shafrina \& Raisa, A. 2011. Penggunaan DNA barcode sebagai alternatif identifikasi spesies udang mantis. http://repository.ipb.ac.id 
Situmeang, N. S., Purnama, D., \& Hartono, D. (2017). Identifikasi spesies udang mantis (Stomatopoda) di perairan Kota Bengkulu. Jurnal Enggano, 2(2): 239-248.

Wardiatno, Y., Farajallah, A., \& Ali, M. 2009. Kajian aspek reproduksi dan genetika udang mantis (Harpiosquilla raphidea, Fabricius 1798) di Kuala Tungkal, Kabupaten Tanjung Jabung Barat, Jambi. sebagai upaya lanjutan domestikasi udang mantis. Laporan Penelitian. Lembaga Penelitian dan Pengabdian Kepada Masyarakat. Institut Pertanian Bogor, 36 hlm.

Wang, T.W. 2005. Harpiosquilla harpax (deHaan,1844) harp prawn. http:// taibif.tw/zh/namecode/40322 3. 13 Juli 2018. 